\title{
WATERS SUITABILITY FOR TILAPIA (Orechromis niloticus) CULTIVATION IN CAGE CULTURE IN LAKE RANAU, LAMPUNG
}

\author{
Emilyasari Desy*, Student \\ Andayani Sri, Harahab Nuddin, Lecturers \\ Faculty of Fisheries and Marine Science, University of Brawijaya, Indonesia \\ *E-mail: emilyasaridesy@gmail.com
}

\begin{abstract}
Water suitability is an effort to see the water potential to support the aquaculture development. Cultivation area study is the first step to know the water suitability level for established cage units of tilapia. Some of key factors for cultivation effort are area selection for the right water quality. This study aims to determine water suitability level for tilapia cultivation in cage culture based on water quality factor. The main parameters measured in this study were water temperature, $\mathrm{pH}$, dissolved oxygen, water clarity, current velocity, total ammonia nitrogen, nitrate, phosphate and chlorophyll-a. The research was conducted in the Lake Ranau ten areas of sampling location. The results of in-situ measurements and the laboratory analysis results (ex situ) were analyzed descriptively to determine water suitability level by scoring and weighting based on literature sources. The suitability class obtained in all stations shows the general waters of Lake Ranau in Lumbok Seminung highly suitable to establish tilapia farming through cage culture.
\end{abstract}

\section{KEY WORDS}

Suitability, water quality, lake, cage culture, Tilapia.

Lake Ranau is administratively located in Lampung Province and South Sumatra Province. Its geographical position is between $4^{0} 51^{\prime} 59^{\prime \prime}-4^{0} 58^{\prime} 42^{\prime \prime} S$ and between $103^{\circ} 55^{\prime}$ 07 " $-104^{\circ} 01^{\prime} 37^{\prime \prime} \mathrm{E}$. The size of entire lake surface is $125.9 \mathrm{~km}^{2}$, with $84.23 \mathrm{~km}^{2}$ located in South Sumatra and $41.67 \mathrm{~km}^{2}$ located in Lampung Province. This lake belongs to volcanic type. The maximum depth of approximately $229 \mathrm{~m}$ and the average depth of $78.0 \mathrm{~m}$ (Aisha et al., 2015).

Lake Ranau is located in Lampung Province covering $41.67 \mathrm{~km}^{2}$ into the administrative area of District Lumbok Seminung, West Lampung Regency. Until now, the location has the potential to be utilized in the field of fisheries. One factor is due to the location that is easily accessible by vehicle.

Cage Culture (KJA) is a series of floating framework to place cultivated container nets. KJA consists of cage (net) and frame (raft and iron) with same size. Some of the determinants of the successful KJA cultivation business are choosing the right location and considering the water quality factor.

The water quality of a region is determined by the physical, chemical, and biological characteristics of the waters. The interaction between these three traits determines water's ability to support organism life in it. Physical and chemical characteristics of water are very influential on aquatic life. Characteristics encompassing temperature, clarity, depth, $\mathrm{pH}$, dissolved oxygen, total ammonia nitrogen (TAN), nitrate, phosphate and chlorophyll-a are the factors that need to be observed in determining the waters suitability for aquaculture (Venturoti et al., 2015). The purpose of this study is to determine water suitability level based on water quality parameters in the waters of Lumbok Seminung, Lake Ranau for the tilapia cultivation in cage culture.

\section{MATERIALS AND METHODS OF RESEARCH}

This research was conducted in Lumbok Seminung, Lake Ranau, Lampung Barat District of Lampung Province, implemented in April 2018 with 10 sampling stations (Fig. 1). 


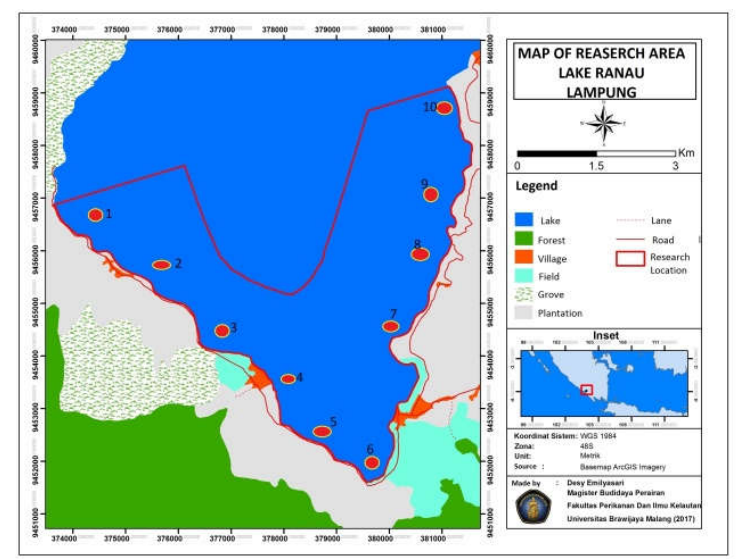

Figure 1 - Research Location Map

Parameters measured directly (in situ) include: temperature, $\mathrm{pH}, \mathrm{DO}$, brightness and current velocity. Parameters measured in the laboratory (ex situ) include: TAN, nitrate, phosphate and chlorophyll-a.

Chlorophyll-a analysis was performed by taking 1 liter of water samples at the site and then inserted in dark bottles, and stored in a cool box with low temperature, then analyzed in a laboratory by a formula (Parsons et al. 1984):

$$
\text { Chlorophyl }-\mathrm{a}\left(\frac{\mathrm{mg}}{\mathrm{l}}\right)=\left(\frac{\mathrm{Ca} \times \mathrm{Va}}{\mathrm{V} \times \mathrm{d}}\right)
$$

Where:

$\mathrm{Va}=$ Aseton volume $(10 \mathrm{ml}) ;$

$V=$ Filtered water sampel volume $(\mathrm{ml})$;

$\mathrm{d}=$ cuvet diameter $(1 \mathrm{~mm})$;

$\mathrm{Ca}=(11,6 \times \mathrm{E} 665)-(1,31 \times \mathrm{E} 645)-(0,14 \times \mathrm{E} 630) ;$

$E=$ Absorbance at different wavelengths (corrected with $750 \mathrm{~nm}$ wavelengths).

Weighting and Scoring. Suitability class is determined by compiling a matrix of conformity which contains parameters that become the requirement of tilapia growth and development, and then determine the value limits for each parameter that meets the requirements of tilapia farming.

Weighting on each parameter is determined based on the dominance of these factors on a feasibility designation of tilapia farming land. The water suitability class interval is obtained based on the equal interval method, ie the interval of each class is obtained from the multiplication of the maximum value of each weight and the score minus the total multiplication of its minimum value which is then divided by the number of classes (Prahasta, 2013). The suitability class is divided into three classes, which are highly suitable (S1), suitable (S2) and less suitable (N) (Perez et al., 2005).

Suitability Class. The following formula is used to determine the total score:

$$
N=\frac{\mathrm{Bi} \times \mathrm{Si}}{\text { Total Weight }}
$$

Where:

$\mathrm{N}=$ Total score;

$\mathrm{Bi}=$ Weight on each criterion;

$\mathrm{Si}=$ Score on each criterion.

To determine the suitability class is used the following formula:

$$
\text { Class Interval }=\frac{\Sigma \mathrm{N} \cdot \max -\Sigma \mathrm{N} \cdot \mathrm{min}}{\text { Number of class }}
$$


Operationally this research is divided into two stages. The first stage is collecting data from the water quality parameters of constituent land suitability analysis for the tilapia cultivation by measuring in situ and ex situ. The second stage is the weight calculation and determination of each criterion by Analytical Hierarchy Process (AHP) method as a decision support system (Saaty, 1980). In this study, the importance of each criterion is based on interviews with experts.

\section{RESULTS AND DISCUSSION}

The result of temperature measurement on all stations has relatively the same result, the average is $29.11{ }^{\circ} \mathrm{C}$ (Table 1). Based on the calculation of weight with AHP known temperature has a weight of $13.4 \%$ (Table 2) and is in the 4th rank in relation to determination of water suitability. Based on the land suitability criteria for tilapia farming, the value of the incoming category temperature is very suitable for tilapia farming.

Table 1 - Water Quality Measurement Result

\begin{tabular}{|c|c|c|c|c|c|c|c|c|c|c|}
\hline \multirow[b]{2}{*}{ Station } & \multicolumn{9}{|c|}{ Parameter } & \multirow[b]{2}{*}{$\begin{array}{c}\text { Chlor.-a } \\
\text { (mg/l) }\end{array}$} \\
\hline & $\begin{array}{c}\text { Temp. } \\
\left({ }^{\circ} \mathrm{C}\right)\end{array}$ & $\mathrm{pH}$ & $\begin{array}{c}\mathrm{DO} \\
(\mathrm{mg} / \mathrm{l})\end{array}$ & $\begin{array}{l}\text { Water } \\
\text { clarity } \\
(\mathrm{m})\end{array}$ & $\begin{array}{l}\text { Current } \\
\text { (cm/det) }\end{array}$ & $\begin{array}{l}\text { Depth } \\
\text { (m) }\end{array}$ & $\begin{array}{l}\text { TAN } \\
(\mathrm{mg} / \mathrm{l})\end{array}$ & $\begin{array}{c}\text { Nitrate } \\
(\mathrm{mg} / \mathrm{l})\end{array}$ & $\begin{array}{l}\text { Phosphate } \\
\text { (mg/l) }\end{array}$ & \\
\hline 1 & 29.8 & 8.1 & 8.32 & 6.5 & 0.01 & 75 & 0.031 & 0.074 & 0.075 & 4.32 \\
\hline 2 & 28.6 & 7.5 & 7.22 & 5.5 & 0.01 & 75 & 0.034 & 0.067 & 0.056 & 5.86 \\
\hline 3 & 29.5 & 8.5 & 7.85 & 6 & 0 & 50 & 0.092 & 0.063 & 0.031 & 4.31 \\
\hline 4 & 28.3 & 7.8 & 8.15 & 5.5 & 0 & 75 & 0.038 & 0.094 & 0.033 & 5.97 \\
\hline 5 & 29.3 & 8.2 & 8.69 & 5.5 & 0.02 & 30 & 0.041 & 0.168 & 0.097 & 4.83 \\
\hline 6 & 30.2 & 8.5 & 7.75 & 5 & 0.01 & 25 & 0.042 & 0.161 & 0.102 & 5.94 \\
\hline 7 & 29.4 & 8.3 & 8.48 & 6.5 & 0 & 30 & 0.014 & 0.078 & 0.056 & 4.41 \\
\hline 8 & 27.5 & 8.5 & 7.53 & 5 & 0.01 & 30 & 0.035 & 0.132 & 0.045 & 5.04 \\
\hline 9 & 28.3 & 8.2 & 8.13 & 6 & 0 & 50 & 0.042 & 0.512 & 0.166 & 5.44 \\
\hline 10 & 30.2 & 8.3 & 7.84 & 5.5 & 0.03 & 75 & 0.022 & 0.071 & 0.065 & 4.41 \\
\hline
\end{tabular}

The $\mathrm{pH}$ measurements at each station show values ranging from 7.5 to 8.5 (Table 1). Several factors that influence the $\mathrm{pH}$ value are photosynthesis activity, temperature, and the presence of anions and cations. However, the $\mathrm{pH}$ value range is still within the optimal range for tilapia farming (Cahyono, 2000).

The availability of dissolved oxygen is important for the fish health and survival in cages. The DO measurement results vary across stations, ranging from 7.22 to 8.69 . High DO is at station 5 . The DO range on stations 2 and 4 falls into very suitable categories and other stations are categorized accordingly. Tilapia requires a concentration of $4 \mathrm{mg} / \mathrm{l}$ dissolved oxygen or greater to maintain good fish health and feed conversion (Masser, 1997). Based on the calculation of weight with AHP, is known the DO has the highest weight of $16.4 \%$ in relation to determination of water suitability.

Table 2 - The result of Scoring and Weighting (1)

\begin{tabular}{|c|c|c|c|c|c|c|c|c|c|c|c|c|c|c|c|}
\hline \multirow{3}{*}{ Station } & \multicolumn{15}{|c|}{ Criteria } \\
\hline & \multicolumn{3}{|c|}{$\mathrm{DO}(\mathrm{mg} / \mathrm{l})$} & \multicolumn{3}{|c|}{ Current $(\mathrm{cm} / \mathrm{sec})$} & \multicolumn{3}{|c|}{ TAN (mg/l) } & \multicolumn{2}{|c|}{ Temp. } & \multicolumn{3}{|c|}{$\mathrm{pH}$} & \multirow[b]{2}{*}{$\mathrm{S}$} \\
\hline & $\mathrm{N}$ & B & S & $\mathrm{N}$ & B & S & $\mathrm{N}$ & B & S & $\mathrm{N}$ & B & S & $\mathrm{N}$ & B & \\
\hline 1 & 5 & 16.4 & 82 & 5 & 14.7 & 73.5 & 3 & 13.6 & 40.8 & 5 & 13.4 & 67 & 3 & 10.9 & 32.7 \\
\hline 2 & 5 & 16.4 & 82 & 5 & 14.7 & 73.5 & 3 & 13.6 & 40.8 & 5 & 13.4 & 67 & 5 & 10.9 & 54.5 \\
\hline 3 & 5 & 16.4 & 82 & 5 & 14.7 & 73.5 & 3 & 13.6 & 40.8 & 5 & 13.4 & 67 & 3 & 10.9 & 32.7 \\
\hline 4 & 5 & 16.4 & 82 & 5 & 14.7 & 73.5 & 3 & 13.6 & 40.8 & 5 & 13.4 & 67 & 5 & 10.9 & 54.5 \\
\hline 5 & 5 & 16.4 & 82 & 5 & 14.7 & 73.5 & 3 & 13.6 & 40.8 & 5 & 13.4 & 67 & 3 & 10.9 & 32.7 \\
\hline 6 & 5 & 16.4 & 82 & 5 & 14.7 & 73.5 & 3 & 13.6 & 40.8 & 5 & 13.4 & 67 & 3 & 10.9 & 32.7 \\
\hline 7 & 5 & 16.4 & 82 & 5 & 14.7 & 73.5 & 5 & 13.6 & 68 & 5 & 13.4 & 67 & 3 & 10.9 & 32.7 \\
\hline 8 & 5 & 16.4 & 82 & 5 & 14.7 & 73.5 & 3 & 13.6 & 40.8 & 3 & 13.4 & 40.2 & 3 & 10.9 & 32.7 \\
\hline 9 & 5 & 16.4 & 82 & 5 & 14.7 & 73.5 & 3 & 13.6 & 40.8 & 5 & 13.4 & 67 & 3 & 10.9 & 32.7 \\
\hline 10 & 5 & 16.4 & 82 & 5 & 14.7 & 73.5 & 3 & 13.6 & 40.8 & 5 & 13.4 & 67 & 3 & 10.9 & 32.7 \\
\hline
\end{tabular}


The water clarity of the Lake Ranau is in a very suitable condition to support the tilapia cultivation. The whole station has an almost equal clarity between 5-6 meters. In comparison, Sudarmadji et al., (2012), measured water quality in Lake Tondano waters with a clarity level of about 2-3 meters which means that solar radiation can reach a depth of 3 meters and is supported by the availability of nutrients (Nitrogen) causing photosynthesis to take place so the growth of phytoplankton increases at a depth of 3 meters. Clarity has the weight of the assessment of the waters suitability by $6.9 \%$, where clarity is one important factor to support the establishment cage culture cultivation.

Current velocity measurements at all observation stations are in the same relative condition, which does not have current. Research conducted by Harsono et al. (2002) at Ranau Lake states that the current pattern is not affected by inlet flow discharge. Surface current pattern is more influenced by coriolis factor. Selection of location for cultivation of KJA must have current condition which is not very strong but still there is current so that water change still happened well and dissolved oxygen content in fish cultivation contained enough, the current can also wash away the remnants of feed and droppings of fish that fall in base waters (Beveridge, 1987).

Water depth relating to the placement and installation of cages. The measurement results show depth ranges from $25-75 \mathrm{~m}$. Based on the suitability class for tilapia farming in cage culture, the depth is categorized as appropriate and less suitable. Where at a depth of more than $30 \mathrm{~m}$ will complicate the installation of cage culture and will increase the cost for installation of cage culture. This is a limiting factor for cage culture development (Subandar et al., 2005).

Ammonia is present in two forms: NH4 (ionized ammonia, since it has a positive ion) and $\mathrm{NH} 3$ (unionized, because it has no ions), which is a total of Ammonia Nitrogen (TAN). The proportions vary depending on the $\mathrm{pH}$ and temperature. If the $\mathrm{pH}$ and temperature increase then the amount of $\mathrm{NH} 3$ increases. It is important to know because $\mathrm{NH} 3$ is a form of toxic ammonia (Sumoharjo, 2009). Ammonia measurements show values between 0.014 $0.092 \mathrm{mg} / \mathrm{I}$. Based on the criteria of conformity of tilapia cultivation, the range $0-0.02 \mathrm{mg} / \mathrm{I}$ is the most suitable for tilapia farming. The highest TAN value is at station 3 with a value of $0.092 \mathrm{mg} / \mathrm{I}$ but the value is still tolerable tilapia that is not more than $0.2 \mathrm{mg} / \mathrm{I}$ (Swayer and McCarty, 1978).

Table 3 - The result of Scoring and Weighting (2)

\begin{tabular}{|c|c|c|c|c|c|c|c|c|c|c|c|c|c|c|c|c|}
\hline \multirow{3}{*}{ Station } & \multicolumn{15}{|c|}{ Criteria } & \multirow{3}{*}{ Tota } \\
\hline & \multicolumn{3}{|c|}{ Depth (m) } & \multicolumn{3}{|c|}{ Clarity (m) } & \multicolumn{3}{|c|}{ Chlor. (mg/l) } & \multicolumn{3}{|c|}{$\mathrm{PO} 4(\mathrm{mg} / \mathrm{l})$} & \multicolumn{3}{|c|}{ NO3 $(\mathrm{mg} / \mathrm{l})$} & \\
\hline & $\mathrm{N}$ & B & S & $\mathrm{N}$ & $B$ & $S$ & $\mathrm{~N}$ & $B$ & S & $\mathrm{N}$ & B & $\mathrm{S}$ & $\mathrm{N}$ & B & S & \\
\hline 1 & 1 & 9.9 & 9.9 & 5 & 6.9 & 34.5 & 5 & 6.5 & 32.5 & 5 & 4.4 & 22 & 5 & 3.4 & 17 & 412 \\
\hline 2 & 1 & 9.9 & 9.9 & 5 & 6.9 & 34.5 & 5 & 6.5 & 32.5 & 5 & 4.4 & 22 & 5 & 3.4 & 17 & 434 \\
\hline 3 & 1 & 9.9 & 9.9 & 5 & 6.9 & 34.5 & 5 & 6.5 & 32.5 & 5 & 4.4 & 22 & 5 & 3.4 & 17 & 412 \\
\hline 4 & 1 & 9.9 & 9.9 & 5 & 6.9 & 34.5 & 5 & 6.5 & 32.5 & 5 & 4.4 & 22 & 5 & 3.4 & 17 & 434 \\
\hline 5 & 5 & 9.9 & 49.5 & 5 & 6.9 & 34.5 & 5 & 6.5 & 32.5 & 5 & 4.4 & 22 & 5 & 3.4 & 17 & 452 \\
\hline 6 & 5 & 9.9 & 49.5 & 5 & 6.9 & 34.5 & 5 & 6.5 & 32.5 & 5 & 4.4 & 22 & 5 & 3.4 & 17 & 452 \\
\hline 7 & 5 & 9.9 & 49.5 & 5 & 6.9 & 34.5 & 5 & 6.5 & 32.5 & 5 & 4.4 & 22 & 5 & 3.4 & 17 & 479 \\
\hline 8 & 5 & 9.9 & 49.5 & 5 & 6.9 & 34.5 & 5 & 6.5 & 32.5 & 5 & 4.4 & 22 & 5 & 3.4 & 17 & 425 \\
\hline 9 & 1 & 9.9 & 9.9 & 5 & 6.9 & 34.5 & 5 & 6.5 & 32.5 & 5 & 4.4 & 22 & 5 & 3.4 & 17 & 412 \\
\hline 10 & 1 & 9.9 & 9.9 & 5 & 6.9 & 34.5 & 5 & 6.5 & 32.5 & 5 & 4.4 & 22 & 5 & 3.4 & 17 & 412 \\
\hline
\end{tabular}

The nitrate content in all stations is at a low value, between $0.06-0.512 \mathrm{mg} / \mathrm{I}$. Based on the suitability class according to Government Regulation No. 82/2001 on water quality standards for aquaculture is less than $5 \mathrm{mg} / \mathrm{I}$. The value goes in very suitable condition. Nitrate (NO 3) is a major nutrient for phytoplankton growth. In tilapia cultivation, the presence of phytoplankton is also an important thing as a natural food for fish. According to Wardoyo (1982), the optimum nitrate content for phytoplankton growth ranges from 0.9 to $3.5 \mathrm{mg} / \mathrm{I}$. Nitrate is a parameter of the trophic status in a waters, nitrates have an effect on nutrients that play a role in the formation of biomass of aquatic organisms (Hasim et al., 2015). The average nitrate value measurement of $0.142 \mathrm{mg} / \mathrm{I}$ indicates that the trophic status water is oligotrophic (Wetzel, 1975). 
Phosphates are a major source of nutrients for the growth of plankton, algae and other bio-vegetable microorganisms (Tatangindatu et al., 2013). Government Regulation No. 82/2001 on Water Quality Management and Water Pollution Control, phosphate content for water body class II is $0.2 \mathrm{mg} / \mathrm{l}$. The highest phosphate values at stations 6 and 9 reached $0.166 \mathrm{mg} / \mathrm{I}$. Based on the trophic status level, these values indicate waters with eutrophic waters category (Wetzel, 1975). While at other stations the phosphate value range of 0.031$0.037 \mathrm{mg} / \mathrm{I}$, also indicates the level of eutrophic throphic status. In relation to the suitability of tilapia cultivation, the value is suitable for cultivation.

Chlorophyll-a is one method that can be used to predict the ability photosynthesis of phytoplankton in waters. the higher a-chlorophyll in a waters, the higher productivity of waters so that the carrying capacity of the inhabitant community is also higher (Riyono et al., 2006). The value of chlorophyll-a in all stations ranged from 4.3 to $5.9 \mathrm{mg} /$ I with an average grade of $5.05 \mathrm{mg} / \mathrm{I}$. Based on the grade of conformity value is very suitable to support the cultivation of tilapia.

Based on the multiplication of weights and scores obtained the results of all stations classified in the class is very appropriate. Total score between 368-500 (Table 3) is S1 category or very suitable for established cage culture fish cultivation, but there are factors that become limiting for established cage culture that is from depth parameter. The deep waters can be overcome with slightly higher installation costs.

\section{CONCLUSION}

Based on the results of research that has been done around Lumbok Seminung Lake Ranau waters, it can be concluded the suitability level of water quality parameters for the cultivation of tilapia in general is very suitable (S1) to established cage culture cultivation of tilapia. The factor that can be a barrier is the depth of the waters.

\section{REFERENCES}

1. Aisyah et al. 2015. Pendugaan Distribusi Spasial Ikan Secara Hidroakustik di Danau Ranau Sumatera. Unpublished Thesis. Graduate Program, Institut Pertanian Bogor.

2. Beveridge, M. 1987. Cage Aquaculture. Fishing News Books Ltd. England, 352 pp.

3. Harsono, E., I. Ridwansyah dan H. Wibowo. 2002. Estimasi Pola Arus Limnologi Danau Ranau. Pusat Penelitian Limnologi-LIPI

4. Parsons, T. R., M. Takashi, and B. Hargrave. 1984. Biological Oceanography Process. Third Edition. Pagaman Press, New York. 263p.

5. Perez, O.M., T.C Telfer, and L.G Ross. 2005. Geographical Information Systems-based Models for Offshore Floating Marine Fish Cage Aquaculture Site Selection in Tenerife , Canary Islands. Aquaculture Research 36, 946-961.

6. Sudarmadji., S. 2012. Dampak Penggunaan Lahan Daerah Tangkapan dan Pemanfaatan Perairan Danau pada Eutrofikasi dan Keberlanjutan Danau Tondano Provinsi Sulawesi Utara. Proceeding. Seminar Nasional Limnologi VI Tahun 2012.

7. Tatangindatu. F., O. Kalesaran dan R. Rompas. 2013. Studi Parameter Fisika Kimia Air pada Areal Budidaya Ikan di Danau Tondano, Desa Paleloan, Kabupaten Minahasa. Budidaya Perairan Mei 2013. Vol. 1 No $2: 8-19$

8. Masser, M.P. 1997. Cage Culture Site Selection and Water Quality. Southern Regional Aquaculture Center. SRAC Publication No. 161

9. Venturoti, G.P., A.C. Veronez, R.V. Salla, and L.C. Gomes. 2015. Variation of Limnological Parameters in a Tropical Lake used for Tilapia Cage Farming. Aquaculture Reports 2 (2015) 152-157. www.elsevier.com/locate/aqrep

10. Wetzel, R.G. 1975. Limnology. Philadelphia: W.B. Sounders Company. 